Environment Conservation Journal 15(1 \&2)89-93, 2014

ISSN 0972-3099 (Print) 2278-5124 (Online)

Abstracted and Indexed

\title{
Assessment of air pollution tolerance levels of some plant species of Jammu
}

\author{
Barneet Kour and Anil K. Raina $\bowtie$
}

Received:18.02.2014

Revised: 12.04.2014

Accepted: 21.04.2014

\begin{abstract}
The air pollution tolerance indices (APTI) of four plant species: Ficus religiosa, Polyalthia longifolia, Pterospernum acerifolium and Thevetia peruviana growing along roadsides at polluted site (Satwari-Bikram Chowk road) in Jammu city has been worked out and compared with the plants growing at the reference location (New University Campus) to categorize plants as sensitive or resistant. The plants were analysed for leaf relative water content (RWC), ascorbic acid content (AA), total leaf chlorophyll ( $\mathrm{T} \mathrm{Ch}$ ) and leaf extract pH to compute the APTI values which indicated that all plants belong to sensitive category as per the index range given by Gaikwad et al. (2006). The values of all the studied biochemical parameters and APTI has been observed to decline in the plants growing at polluted sites in comparison to plants growing at reference site. However, among the plant species growing at polluted site, Ficus religiosa has been observed to be comparatively more tolerant against air pollutants with a maximum APTI value (4.76 \pm 0.16$)$ whereas Pterospernum acerifolium is more sensitive to air pollutants with minimum APTI value (1.65 \pm 0.19$)$. The order of tolerance among these plants has been observed to be: Ficus religiosa> Polyalthia longifolia $>$ Thevetia peruviana> Pterospernum acerifolium. The result also indicated that combining variety of these parameters gave a more reliable result than those of individual parameter.
\end{abstract}

Keywords: APTI, ascorbic acid, total leaf chlorophyll, pH, sensitive, tolerant

\section{Introduction}

Today's growing population and increasing urbanization has resulted in deterioration of ambient air quality. Air pollution is one of the greatest environment evils. It is known fact that $60 \%$ of air pollution in city is caused by automobiles only (Gaikwad, et al., 2004). Vehicles in major metropolitan cities of India are estimated to account for $70 \%$ of $\mathrm{CO}, 50 \%$ of $\mathrm{HC}$ 's, $30-40 \%$ of NOx, $30 \%$ of SPM and $10 \%$ of $\mathrm{SO}_{2}$ of total load of these cities, of which $2 / 3^{\text {rd }}$ is contributed by 2 wheelers alone. This rapid growth of motor vehicles ownership and activities in Indian cities are causing a wide range of serious health, environmental and socio-economic impacts (Khare et al., 2012). Air pollutants, both gaseous and particulate, are known to produce a measurable effect on plants. Since plants are stationary and are continuously exposed to chemical pollutants from the surrounding atmosphere, air pollution injury to plants is proportional to the intensity of the pollution. The adverse effects of air pollutants on

\section{Author's Address}

Department of Environmental Sciences, University of Jammu, Jammu, Jammu

Email: anilkraina@yahoo.com different plant species have been reported by several workers (Kousar et al., 1999; Mashitha and Pise, 2001; Raina and Sharma, 2003; Raina and Aggarwal, 2004; Mandal, 2006; Joshi \& Bora, 2011; Senthilkumar and Paulsamy, 2011; Thambavani and Sabitha, 2011; Gharge and Menon, 2012; Nugraharani et al., 2012 and Radhapriya et al., 2012). The sensitivity towards air pollution varies across the plant community and some being 'tolerant' showing no or minimal symptoms even if the air pollutants increase. Selection of air pollution tolerant and sensitive plant species has a significant impact in determination and reclamation of air pollutants. The variations in biochemical parameters in the leaves can be used as indicators of air pollution for early diagnosis of stress or as marker for various physiological and biochemical parameters. The impact can also be used for monitoring of air pollution in medium to large towns and cities in terms of air pollutant concentration to observe the air quality of the locality. The plant response to air pollution varies from species to species and also in terms of type of pollutant, its reacting mechanism, concentration and duration of exposure (Thambavani and Sabitha, 2011). The air pollution 
tolerance index (APTI) has been used for identifying tolerance levels of plant species. Air pollution tolerance index has also been used to rank plant species in their order of tolerance to air pollution. The aim of this study is to determine the APTI values of four plant species growing along roadsides in Jammu city.

\section{Material and Methods \\ Study area}

The present study has been conducted in Jammu city (latitude $32^{\circ} 44^{\prime} \mathrm{N}$, longitude $74^{\circ} 55^{\prime} \mathrm{E}$ and altitude $400 \mathrm{~m}$ ). It is situated in sub-tropical part and is surrounded by Shivalik range in the North, East and Southeast while the Trikuta Range surrounds it in the North-West. A thorough survey of Jammu city has been done to select two different sites, where the selected plant species are growing under almost similar ecological and edaphic conditions. Road from Satwari to Bikram chowk has been selected as the polluted site. This site is characterised with a high density of vehicles. University campus with a very low traffic flow rate has been selected as reference site.

\section{Selection of Plant species}

For the present study, four plant species growing at polluted and reference sites have been selected viz. Pterospernum acerifolium (L.) Willd., Ficus religiosa L., Polyalthia longifolia Sonn., and Thevetia peruviana (Pers.) K. Schum. Fully mature leaves of almost same age and size (i.e. $4^{\text {th }}$ from tip) were collected in morning hours from the selected trees. Utmost care was taken that the samples from each site were collected from plants growing in isoecological conditions of light, water and soil. A composite sample of each plant species was collected and immediately taken to the laboratory for analysis.

\section{Analysis of various parameters}

The fresh samples were analyzed for various physiological and biochemical parameters viz. total chlorophyll, ascorbic acid, leaf extract $\mathrm{pH}$ and relative water content. By combining these parameters, the 'Air pollution Tolerance Index' (APTI) was computed. The $\mathrm{pH}$ values were estimated by using a digital calibrated $\mathrm{pH}$ meter (Mettler Toledo LE- 438). Ascorbic acid was estimated by 2,6 - dichlorophenol indophenols dye following the method suggested by Sadasivam and Manickam (1996). Total chlorophyll of plant extract was estimated by spectrophotometric method as suggested by Hiscox and Israelstam (1979). Relative water content was estimated by using the following relation:

$$
\text { RWC }=\frac{\text { F.W. } \cdot-\text { D.W. }}{\text { T.W. }- \text { D.W. }}
$$

where, F.W.= Fresh weight, D.W.= Dry Weight and T.W.= Turgid weight

The 'Air Pollution Tolerance Index' (APTI) was determined by using the following formula given by Agarwal (1991):

$$
\mathbf{A P T I}=\{\mathbf{A}(\mathbf{P}+\mathbf{T})+\mathbf{R}\} / 10
$$

Where, $A=$ Ascorbic acid (mg/100g fresh wt.)

$\mathrm{T}=$ Total Chlorophyll ( $\mathrm{mg} / \mathrm{g}$ fresh wt.)

$\mathrm{P}=\mathrm{pH}$ of leaf extract.

$\mathrm{R}=$ Relative water content of leaf tissue (\%).

The entire sum was divided by 10 to obtain a small manageable figure.

Classification of plants into different categories of tolerance levels has been done as per Gaikwad et al, (2006). \{APTI index range: 0 to 1 - most sensitive, 1 to 16 - sensitive, 17 to 29 - intermediate and 30 to 200 - tolerant

\section{Results and Discussion}

Air pollution tolerance index is an index which denotes capability of a plant to combat against air pollution. Plants which have higher index value are tolerant to air pollution and can be used as sink to mitigate pollution, while plants with low index value show less tolerance and can be used to indicate levels of air pollution (Singh and Rao, 1983). Air Pollution Tolerance Index (APTI), calculated for four plant species growing along roadsides in control and polluted sites has been depicted in Table-1. All biochemical parameters that are analysed for APTI play significant role to determine resistivity and susceptibility of plant species. Air Pollution Tolerance Index gives an empirical value for tolerance level of plants to air pollution. 


\section{Ascorbic acid}

Being a very important reducing agent ascorbic acid also plays a vital role in cell wall synthesis, defence and cell division in plants (Conklin, 2001). The reducing power of ascorbic acid is directly proportional to its concentration (Lewin, 1976). In the present study, reductions in ascorbic acid content values in all the species growing at polluted sites were recorded in comparison toreference location. Maximum reduction in ascorbic acid content was observed in Polyalthia longifolia (47.06\%) and least reduction was recorded in Ficus religiosa (7.69\%).

Table- 1: Estimation of the various biochemical parameters in the selected plants

\begin{tabular}{|c|c|c|c|c|c|c|c|c|c|c|}
\hline \multirow[t]{2}{*}{$\begin{array}{l}\text { Name of the } \\
\text { plant species }\end{array}$} & \multicolumn{2}{|c|}{$\begin{array}{l}\text { Ascorbic Acid } \\
\text { (mg } 100 \mathrm{~g}^{-1} \text { f wt.) }\end{array}$} & \multicolumn{2}{|l|}{ pH } & \multicolumn{2}{|c|}{$\begin{array}{l}\text { Relative Water } \\
\text { Content } \\
\text { (\%RWC) }\end{array}$} & \multicolumn{2}{|c|}{$\begin{array}{l}\text { Total Chlorophyll } \\
\text { (mg g } \text { f }^{-1} \text { wt.) }\end{array}$} & \multicolumn{2}{|c|}{$\begin{array}{l}\text { Air Pollution } \\
\text { Tolerance Index } \\
\{\text { APTI }= \\
\mathbf{A}(\mathbf{P}+\mathbf{T})+\mathbf{R} / \mathbf{1 0}\}\end{array}$} \\
\hline & 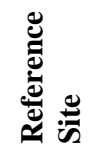 & 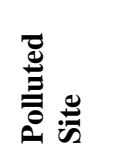 & 窇 & 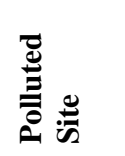 & 窇 & 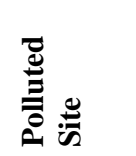 & 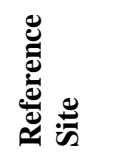 & 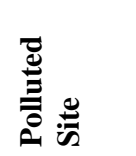 & 苞 & 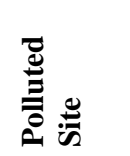 \\
\hline $\begin{array}{l}\text { Pterospernum } \\
\text { acerifolium }\end{array}$ & $\begin{array}{l}0.09 \\
\pm 0.01\end{array}$ & $\begin{array}{l}0.07 \\
\pm 0.04 \\
(22.22 \%) \\
\end{array}$ & $\begin{array}{l}6.76 \\
\pm 0.06\end{array}$ & $\begin{array}{l}6.62 \\
\pm 0.06 \\
(2.07 \%)\end{array}$ & $\begin{array}{l}25.20 \\
\pm 1.61\end{array}$ & $\begin{array}{l}16.06 \\
\pm 1.65 \\
(36.27 \%)\end{array}$ & $\begin{array}{l}0.0022 \\
\pm 0.001\end{array}$ & $\begin{array}{l}0.0009 \\
\pm 0.001 \\
(59.09 \%)\end{array}$ & $\begin{array}{l}2.58 \\
\pm 0.15\end{array}$ & $\begin{array}{l}1.65 \\
\pm 0.19 \\
(35.99 \%)\end{array}$ \\
\hline $\begin{array}{l}\text { Ficus } \\
\text { religiosa }\end{array}$ & $\begin{array}{l}0.13 \\
\pm 0.03\end{array}$ & $\begin{array}{l}0.12 \\
\pm 0.04 \\
(7.69 \%)\end{array}$ & $\begin{array}{l}6.53 \\
\pm 0.11\end{array}$ & $\begin{array}{l}6.25 \\
\pm 0.11 \\
(4.29 \%)\end{array}$ & $\begin{array}{l}53.83 \\
\pm 0.90\end{array}$ & $\begin{array}{l}47.10 \\
\pm 1.61 \\
(12.50 \%)\end{array}$ & $\begin{array}{l}0.0027 \\
\pm 0.001\end{array}$ & $\begin{array}{l}0.0012 \\
\pm 0.001 \\
(55.55 \%)\end{array}$ & $\begin{array}{l}5.47 \\
\pm 0.08\end{array}$ & $\begin{array}{l}4.76 \\
\pm 0.16 \\
(12.49 \%)\end{array}$ \\
\hline $\begin{array}{l}\text { Polyalthia } \\
\text { longifolia }\end{array}$ & $\begin{array}{l}0.34 \\
\pm 0.04\end{array}$ & $\begin{array}{l}0.18 \\
\pm 0.04 \\
(47.06 \%)\end{array}$ & $\begin{array}{l}6.47 \\
\pm 0.11\end{array}$ & $\begin{array}{l}6.36 \\
\pm 0.06 \\
(1.70 \%)\end{array}$ & $\begin{array}{l}33.40 \\
\pm 1.34\end{array}$ & $\begin{array}{l}28.60 \\
\pm 0.96 \\
(14.37 \%)\end{array}$ & $\begin{array}{l}0.0026 \\
\pm 0.001\end{array}$ & $\begin{array}{l}0.0011 \\
\pm 0.001 \\
(57.69 \%)\end{array}$ & $\begin{array}{l}3.36 \\
\pm 0.12\end{array}$ & $\begin{array}{l}2.97 \\
\pm 0.12 \\
(11.38 \%)\end{array}$ \\
\hline $\begin{array}{l}\text { Thevetia } \\
\text { peruviana }\end{array}$ & $\begin{array}{l}0.45 \\
\pm 0.05\end{array}$ & $\begin{array}{l}0.29 \\
\pm 0.08 \\
(35.55 \%)\end{array}$ & $\begin{array}{l}6.61 \\
\pm 0.06\end{array}$ & $\begin{array}{l}6.12 \\
\pm 0.05 \\
(7.41 \%)\end{array}$ & $\begin{array}{l}36.50 \\
\pm 6.56\end{array}$ & $\begin{array}{l}15.46 \\
\pm 0.93 \\
(57.64 \%)\end{array}$ & $\begin{array}{l}0.0009 \\
\pm 0.001\end{array}$ & $\begin{array}{l}0.0002 \\
\pm 0.001 \\
(77.78 \%)\end{array}$ & $\begin{array}{l}3.95 \\
\pm 0.05\end{array}$ & $\begin{array}{l}1.72 \\
\pm 0.13 \\
(56.32 \%)\end{array}$ \\
\hline
\end{tabular}

*The figures in parenthesis represent the percent reduction in the values of given parameter at polluted site as compared to values at reference site.

pH: The leaf extract $\mathrm{pH}$ also varies with the variation in the vehicular emissions. The $\mathrm{pH}$ level determines the synthesis and reducing activity of ascorbic acid, being more at higher (Alkaline side, above 7) and less at lower $\mathrm{pH}$ levels. Scholz and Reck (1977) have reported that in presence of an acidic pollutant, the leaf $\mathrm{pH}$ is lowered and the decline is greater in sensitive species. In the present study, reduction in $\mathrm{pH}$ value has been observed in all the plants growing at polluted location in comparison to reference location. Maximum reduction in $\mathrm{pH}$ value was recorded in Thevetia peruviana (7.41\%) and least reduction was recorded in Polyalthia longifolia (1.70\%).

Total Chlorophyll content: Chlorophyll (Chl) content of plants signifies its photosynthetic activity as well as the growth and development of biomass. It varies with the tolerance as well as sensitivity of the plant species i.e. higher the sensitive nature of plant species, lower the chlorophyll content. Degradation of photosynthetic pigment has been widely used as an indicator of air pollution (Ninave et al., 2001). In the present study, the chlorophyll content i.e. chl-a, chl-b and total chl have been observed to be less in selected plants growing at polluted site than in plants at reference site. Maximum reduction in total chlorophyll content was observed in Thevetia peruviana (77.78\%) and least reduction was recorded in Ficus religiosa $(55.55 \%)$.

Relative water content: The relative water content defines the moisture holding capacity of a plant and is indicative of the hydration conditions in the leaf matrix. It represents a useful indicator of the state 
of water of a plant, essentially because it expresses the absolute amount of water, which the plant requires to reach artificial full saturation (González and González-Vilar, 2001). In the present study, reductions in relative water content values in all the species growing along the roadsides at polluted sites have been recorded which indicates their disturbed physiological status due to auto exhaust pollution. Maximum reduction was observed in Thevetia peruviana $(57.64 \%)$ while least reduction was recorded in Ficus religiosa (12.50\%).

APTI: The present observation reveals that all the studied plant species have APTI value $<16$, thereby falling in the sensitive class. However, with respect to their tolerance level they can be arranged in following sequence i.e. Ficus religiosa > Polyalthia longifolia > Thevetia peruviana > Pterospernum acerifolium. The present study indicates that the APTI value of all the plant species at polluted site has been recorded lower than the reference site. Maximum reduction in APTI value was observed in Thevetia peruviana (56.32\%) and least reduction was recorded in Polyalthia longifolia (11.38\%).

\section{Conclusion}

Plants play an important role in monitoring and maintaining the ecological balance by actively participating in the cycling of nutrients and gases like carbon dioxide, oxygen and also provide enormous leaf area for impingement, absorption and accumulation of air pollutants to reduce the pollution level in the environment. The present observation reveals that all the studied plant species falls in the sensitive class. However, in the plant species present at the polluted site, Ficus religiosa registered maximum APTI value $(4.76 \pm 0.16)$ while Pterospernum acerifolium registered minimum APTI value (1.65 \pm 0.19$)$. Therefore, it can be stated that Ficus religiosa is comparatively more tolerant species and Pterospernum acerifolium is comparatively more sensitive species among the four plant species which have been studied.

On the basis of the present work it can be concluded that all the studied plant species i.e. Pterospernum acerifolium, Ficus religiosa, Polyalthia longifolia and Thevetia peruviana are 'sensitive plant species' and can be used as bioindicators for monitoring the air quality of the area.

\section{Acknowledgement}

The authors are highly thankful to the Department of Environmental Sciences, University of Jammu, Jammu for providing necessary facilities to undertake the present investigations.

\section{References}

Agarwal S.K., 1991. Automobile pollution. Ashish Publishing House, New Delhi, pp: 255.

Conklin, P.L., 2001. Recent advances in the role and biosynthesis of ascorbic acid in plants, Plant cell environment, 24: 383-394.

Gaikwad, U.S., Ranade, C.D. and Gadgil, J.M., 2006. Plants as indicators of automobile exhaust pollution, a case study of Sangli City. Journal-EN, 86: 26-28.

González, L. and González- Vilar, M., 2001. Determination of relative water content, In: Reigosa MJ (ed.), Handbook of Plant Ecophysiology Techniques, Kluwer Academic Publishers, Dordrecht, pp: 207-212.

Gharge,S. and Menon, G.S., 2012. Air Pollution Tolerance Index (APTI) of certain herbs from the site around Ambernath MIDC. Asian Journal of Experimental Biological. Sciences, 3(3):543-547.

Hiscox, J.D. and Israelstam, G.M., 1979. A method for extraction of chlorophyll from tissue without maceration. Canadian Journal of Botany, 57(12): 13321334.

Joshi, N. and Bora, Meha, 2011.Impact of air quality on physiological attributes of certain plants. Report and opinion, 3(2):42-47.

Khare, M., Nagendra, S. and Gulia, S., 2012. Performance evaluation of air quality dispersion models at urban intersection of an Indian city: a case study of Delhi city, In: Longhurst, J.W.S and Brebbia, C.A. (eds.), Air Pollution XX, WIT Press, UK, pp: 249-260.

Kousar, N., Seshikala, D. and Acharya, S.M., 1999. Biomonitoring of air pollution by using plants in Wrangal city. Indian journal of environmental protection. 19 (7): 488-492.

Lewin, S. 1976. Vitamin C: Its molecular biology and medical potential, Academic Press, London, pp: 5-6.

Mashitha, P.M. and Pise, V.L., 2001. Biomonitoring of air pollution by correcting the pollution tolerance index of some commonly ground trees of an urban area. Pollution research, 2 (2): 195-197. 
Mandal, M., 2006. Physiological changes in certain test plant under automobile exhaust pollution. Journal of environmental biology, 27 (1): 43-47.

Nandi, P.K.; Agarwal, M., Agarwal, S.B. and Rao, D.N., 1990. Physiological responses of Vicia faba plants to sulphur dioxide. Ecotoxicoloy and Environmental Safety, 19: 6471.

Ninave, S.Y., Chaudhari, P.R., Gajaghate, D.G. and Tarar, J.L., 2001. Foliar biochemical features of plants as indicator of air pollution. Bulletin of environmental contamination and toxicology, 67:133-140.

Nugraharani, P., Prasetyawati, E.T., Sugijanto and Purnobasuki, H., 2012. Ornamental shrubs as plant palettes elements and bioindicators based on air pollution tolerance index in Surbaya city. Asian Journal of Experimental Biological Sciences, 3(2): 298-302.

Radhapriya, P., Navneetha Gopalakrishnan, A., Malini, P. and Ramachandran, A., 2012. Assessment of air pollution tolerance levels of selected plants around cement industry, Coimbatore, India. Journal of environmental biology,33: 635-641.

Raina, A. K. and Sharma, A., 2003. Effect of vehicular pollution on the leaf micro morphology, anatomy and chlorophyll contents of Syzygium cumini Linn. Indian journal of environmental protection. 23 (8): 897-902.

Raina, A. K. and Aggarwal, B., 2004. Effect of vehicular exhaust on some trees in Jammu-II. Journal of industrial pollution control, 20 (2): 229-232.
Sadasivam, S. and Manickam, A., 1996. Biochemical MethodsNew Age International Publishers, pp: 251.

Senthilkumar, P. and Paulsamy, S., 2011. Evaluation of air pollution tolerant tree species for Kothagiri Municipal Town, the Nilgiris, Tamil Nadu. Journal of research in biology, 2: 148-152.

Scholz, F. and Reck, S., 1977. Effects of acids on forest trees as measured by titration invitro inheritance of buffering capacity. Water, air and soil pollution, 8:41-45.

Singh, P.K., 2005. Plants as indicators of air pollution- An Indian experience, Indian forester, 131(1): 71-80.

Singh, S.K. and Rao, D.N., 1983. Evaluation of plants for their tolerance to air pollution, In: Proceedings of symposium on air pollution control, Indian Association for Air Pollution Control. New Delhi, 218-224.

Thambavani, D.S. and Maheswari, J., 2012. Evaluation of Anticipated Performance Index of Certain Tree Species in Virudhunagar, India, International congress on informatics, environment, energy and applications, 38.

Thambavani, D.S. and Sabitha, M.A., 2011. Variation in air pollution tolerance index and anticipated performance index of plants near a sugar factory: implications for landscape-plant species selection for industrial areas. Journal of research in biology, 7: 494-502. 